\title{
The Effect of Audit Quality on Firm Performance: A Panel Data Approach
}

\author{
May M. Elewa (Corresponding author) \\ Accounting, Ahram Canadian University, Egypt \\ E-mail: elewa_may@yahoo.com \\ Rasha El-Haddad \\ Accounting, Ahram Canadian University, Egypt
}

$\begin{array}{lrr}\text { Received: January 3, } 2019 & \text { Accepted: February 4, } 2019 \quad \text { Published: February 13, } 2019 \\ \text { doi:10.5296/ijafr.v9i1.14163 } & \text { URL: https://doi.org/10.5296/ijafr.v9i1.14163 }\end{array}$

\begin{abstract}
This study attempts to examine the effect of audit quality on firm performance. It uses financial statements of non-financial firms listed as EGX 100. The population studied consists of thirty non-financial firms. The study covers a five year period 2010-2014. It applies panel data analysis. Independent Variables are Auditor Experience (measured by Big-4) and Auditor Independence (measured by auditor Rotation ROT). Dependent Variables are Return on Assets ROA and Return on Equity ROE. In accordance with the Random Effect Model results, BIG 4 and ROT have an insignificant impact on the ROA and ROE of the firm. External and internal financial statement users may benefit from the study only when dealing with high-profit firms.
\end{abstract}

Keywords: Auditor quality, Firm performance, Annual reports, Emerging markets

\section{Introduction}

A financial statement audit is an essential tool for reducing information asymmetries and for maintaining an efficient market environment. However, if the audit process is to improve business performance, there must be credibility and reliability regarding audited financial information. Nowadays, due to the information asymmetry and the impact of financial information on investment decisions, the importance of the audit profession has increased. Audit quality has a vital role in strengthening confidence in the credibility and integrity of financial statements which is essential for enhanced firm financial performance (Farouk and 


\section{$\triangle$ Macrothink}

International Journal of Accounting and Financial Reporting

ISSN 2162-3082

2019, Vol. 9, No. 1

Hassan 2014). Also, audit quality ensures the confidence of users in the audit report where they rely on it in making investment decisions.

An auditor has the duty for the avoidance, recognition, and reporting of fraud, other illegal acts, and errors (Oluwagbemiga 2010). This argument has been particularly highlighted by the fall of both small and big corporations worldwide. The role of auditor independence is to improve the financial reporting quality by increasing the effectiveness and efficiency of the audit process and ensuring an auditor is not too familiar with the client to not jeopardize their integrity thus impairing their independent opinion Tobi et al. (2016). The independence of auditors has a vital role in maintaining the confidence of users in the audited financial statements. Some factors may influence auditor independence such as providing non-audit services to the client and having relations with the client firm. Also, if the auditors overstay with a client as extended audit tenure, the independence may be affected (Jackson et al. 2008). So, regulators organized the relationship between the auditor and the client by issuing some rules. The Sarbanes-Oxley (SOX) Act and the Securities \& Exchange Commission (SEC) rules further restrict the type of non-audit services that can be provided by auditors. The Public Company Accounting Oversight Board (PCAOB) has also issued additional independence rules related to the provision of certain tax services Arens et al. (2012). The SOX act requires that the lead and concurring audit partner rotate off the audit engagement after five years Arens et al. (2012). The prohibition of providing specific audit services to the client and audit partner rotation can maintain the auditor independence. Besides, the constant search for increasing firm profitability highlights the importance of enhancing firm financial performance as well.

Lee et al. (2007) investigate whether the impact of the quality of financial statements is higher when financial statements are audited by the big accounting firms. They find that investors are able to better anticipate future earnings when financial statements are audited by the big accounting firms. However, the authors did not find significant results in the more recent years of their sample.

Accordingly, this paper examines the consequences of audit quality on firm performance of firms operating in the Egyptian business environment. It contributes to the literature in the following important ways:

1. It examines the association between the quality of firm financial statements information to Auditor Experience in Egypt.

2. It examines the association between the quality of firm financial statements information to Auditor Independence in Egypt.

3. It examines the degree to which the associations between the quality of financial statements information and firm profitability differ between profitable and unprofitable firms.

As a result of extensive reading, it is clear that no study has been made as of today that verifies the impact of auditor experience (measured by Big 4) and auditor independence (measured by auditor Rotation ROT) on the quality of firm financial statement information in 
Egypt. This is very important in investor decision making. Thus, this work is a reflection of the situation of audit quality on financial statements of operating firms in the Egyptian business environment and perhaps even a beginning to more related future studies on the topic.

The authors organized the rest of the paper in the following manner: Section 2 provides a summary of Previous Research, Theoretical Framework, and Hypotheses Development. Section 3 identifies the Data, Methodology, and Discussion of Empirical Results. Section 4 gives the conclusions and recommendations. Section 5 proposes areas for future research.

\section{Literature Review, Theoretical Background \& Hypotheses Development}

\subsection{Literature Review}

Research studies examine the effect of audit quality on the firm performance. Some of these studies used audit firm size, auditor experience, audit fees, auditor rotation and auditor independence as proxies for audit quality (e.g., Woodland and Reynolds 2003; Nam 2011; Miettinen 2011; Bouaziz 2012; Anderson and Verma 2012; Farouk and Hassan 2014; Tobi et al. 2016; Matoke and Omwenga 2016). (Nam 2011) examines the association between audit fees as a measure for auditor independence and audit quality of firms in New Zealand. The study discovered that the condition of non-audit services by the auditors of a firm compromises the auditor's independence. (Farouk and Hassan 2014) investigate the effect of audit quality on the financial performance of quoted cement firms in Nigeria. They aimed at determining the impact of auditor independence and audit firm size as proxies for audit quality on financial performance using multiple regression analysis. Findings show that audit firm size and auditor independence have significant impacts. However, auditor independence is more influential than auditor size on firm financial performance. (Matoke and Omwenga 2016) test the relationship between audit quality and financial performance through the proxies of auditor independence, auditor size, audit team attributes, auditor experience and net profit margin of listed firms in Kenya. The study analyzed data by applying multiple linear regression analysis. This investigation found that the effect of audit quality on financial performance is positive and significant and the higher the degree of auditor independence, the more likely the firm is to have higher profitability. (Woodland and Reynolds 2003) inspect the relationship between indirect measures of audit quality and financial statement analysis using multivariate regression analysis. They discovered that there is no proof that auditor size, tenure or industry specializations associate with audit quality. (Miettinen 2011) studies the association between audit quality and financial performance. Audit quality was measured using auditor size. The outcome of the study proves that audit quality has a direct effect and a mediated effect through audit size on financial performance. (Bouaziz 2012) studied the association among auditor size and financial performance on a sample of 26 Tunisian firms registered on the Tunis Stock Exchange. The outcome shows that auditor size has a substantial impact on the financial performance of firms concerning Return on Assets ROA and Return on Equity ROE. The study by (Anderson and Verma 2012) examined the relationship between auditor size, auditor tenure, and auditing firm rotation. The data they gathered from 2,148 listed Asian firms shows that big audit firms offer high-quality audit 
because big audit firms are considered more conservative than non-big audit firms. According to (DeAngelo 1981) auditor independence is the restricted possibility that the auditor will reveal any misstatement in financial statements. Also, AICPA and the International Ethics Standards Board for Accountants (IESBA) codes of ethics both identify independence as constituting of two components: independence of mind and independence in appearance. Independence of mind exists when the auditor can maintain an unbiased attitude throughout the audit, whereas independence in appearance is dependent on others' interpretation of this independence and hence their faith in the auditor Arens et al. (2012). Independence of mind entails the auditor to have a state of mind that allows the provision of opinion without being influenced by any pressure that compromise professional judgment, permitting an individual to act with honesty and to be objective and to use professional skepticism. While independence in appearance obliges the auditor to keep away from circumstances that will cause others to conclude that they are not keeping a fair attitude (Farouk \& Hassan 2014).

(Uwuigbe and Olusanmi 2012; Wahla, Shah, and Hussain 2012; Fazlzadeh, Hendi, and Mahboubi 2011; Liang, Lin, and Huang 2011; Ongore 2011; Tsegba and Ezi-Herbert 2011; Mandac and Gumus 2010) all determine the role of ownership structure on firm performance. Both (Uwuigbe and Olusanmi 2012) and (Tsegba and Ezi-Herbert 2011) target Nigerian listed firms. (Wahla, Shah, and Hussain 2012) were undertaken for firms in Karachi while the study of (Fazlzadeh, Hendi, and Mahboubi 2011) focus on listed firms in Tehran. (Liang, Lin, and Huang 2011) explored firms in Taiwan. (Ongore 2011) investigated firms operating in Kenya and (Mandac and Gumus 2010) tested Turkish firms using the ROA and Tobin's Q to represent the firm performance. In (Wahla, Shah, and Hussain 2012) Tobin's Q is used as well to measure firm performance. Results of this study suggested that firm performance critically depends on Managerial Ownership. Also, agency problems arise due to the increase in Managerial Shareholdings thus impacting firm performance. In the study of (Ongore 2011), ownership concentration and owner identity represent ownership structure while ROA, ROE and dividend yield represents firm performance. The study by (Fazlzadeh, Hendi, and Mahboubi 2011) uses the panel data and regression analysis to examine 137 listed firms. The studies consider the ownership concentration, institutional ownership, and institutional ownership concentration variables for the period 2001 to 2006. Results imply that ownership concentration doesn't have any significant effect on firm performance while institutional ownership has a considerable positive effect on firm performance and concentrated institutional ownership has a significant negative effect on firm performance. (Liang, Lin, \& Huang 2011) uses an unbalanced panel data analysis and applies a simultaneous equations framework. Empirical results suggest that firm performance is a function of institutional ownership, especially in the mature stage. (Mandac \& Gumus 2010) test the effects of ownership concentration and managerial ownership on the profitability and the value of non-financial firms registered on the Istanbul Stock Exchange (ISE). After controlling for investment intensity, leverage, growth and size findings show ownership concentration has a significantly positive effect on both firm value and profitability, while managerial ownership has a significantly negative effect on firm value. (Uwuigbe \& Olusanmi 2012) analyzes the corporate annual reports for 31 firms during the period 2006-2010. The study uses the 
multivariate multiple regression analysis methods. Findings showed that institutional ownership has a significant positive impact on firm performance. Moreover, there is a substantial positive association between foreign ownership and firm performance as well. (Wahla, Shah, and Hussain 2012) analyze Managerial Ownership and Concentrated Ownership variables during the period 2008 to 2010. The study uses Panel Data analysis. Findings indicate that Managerial Ownership has a significant negative relationship with Firm Performance, while Concentrated Ownership has shown an insignificant relationship with Firm Performance. After controlling for Leverage, the authors realize a significant negative relationship with Firm Performance while an insignificant relationship with between Assets Turnover and Firm Performance was evident. In the study of (Ongore 2011), Pearson's product moment correlation and logistic regression were used. A sample of 42 listed firms was examined using primary and secondary data. Reliability of data was tested using Cronbach's Alpha, while tolerance and variance-inflation factors were used to test multicollinearity. Results prove that ownership concentration and government ownership have significant negative relationships with Firm Performance, while, Foreign Ownership, Diffuse Ownership, Corporation Ownership, and Manager Ownership were found to have significant positive relationships with Firm Performance. In the study of (Tsegba and Ezi-Herbert 2011), the Ordinary Least Squares (OLS) analysis was applied to a sample of 73 firms covering the period 2001 to 2007. Empirical results indicate that Dominant Shareholding, Concentrated Ownership, and Foreign Ownership structures have no significant effect on Firm Performance and Insider Ownership is inversely related to Firm Performance.

The studies of (Al-Matari, Al-Swidi, Faudziah, and Al-Matari 2012; Najjar 2012; Shan and McIver 2011; Yasser, Entebang and Abu Mansor 2011; Nuryanah and Islam 2011; Obiyo and Lenee 2011; Khan, Nemati, and Iftikhar 2011; Abdurrouf 2011; and Hu, Tam, and Tan 2010) determine the role of corporate governance on firm performance. (Al-Matari, Al-Swidi, Faudziah, and Al-Matari 2012) reported on Saudi firms. (Obiyo and Lenee 2011) reported on firms in Nigeria concluding that the more outsiders there are on a company's board, the better the performance regarding ROE. Also, when a CEO serves as the board chairman, performance worsens. Both (Hu, Tam, and Tan 2010) and (Shan and McIver 2011) reported research results for firms in China. (Khan, Nemati, and Iftikhar 2011) and (Najjar 2012) reported their research results for firms in Bahrain. (Nuryanah and Islam 2011) reported on Indonesian listed firms. (Yasser, Entebang and Abu Mansor 2011) and (Abdurrouf 2011) reported research results on firms in Pakistan. (Abdurrouf 2011) measures corporate governance using board size, independent board director, duality chief executive officer, audit committee board and value of the firm while ROA and ROE measure firm performance. (Obiyo and Lenee 2011) use ROE, Net profit margin, Sales growth, Dividend yield, and Stock prices/values to define the performance of the firm. Board independence, board size, audit independence, ownership, and the progressive practices of the company measure corporate governance. (Shan and McIver 2011) considered the ratios of independent directors and professional supervisors on the company board, and the level of concentration in any ownership of the firms. Tobin's Q measures firm performance. (Yasser, Entebang and Abu Mansor 2011) examines the relationship of board size, board composition, CEO/chairman 
duality and audit committee that represent the corporate governance mechanisms with ROE, and profit margin that represent firm performance measures. the study by (Abdurrouf 2011) analyzes a sample of 93 listed non-financial firms in Dhaka Stock Exchange (DSE) for the financial year 2006. The study applies Ordinary Least Square OLS method. Findings show a significant positive relationship between ROA and board independent director as well as chief executive officer duality. Also, a significant positive relationship between ROE and board independent director as well as chief executive officer CEO duality exists. However, a significant relationship between the ROA and ROE with the board size and board audit committee was not evident. The study of Al-Matari, Al-Swidi, Faudziah, and Al-Matari 2012) examines non-financial listed firms for the financial year 2010. Statistical results show that audit committee size is found to have a significant relationship with firm performance while CEO Duality, Board Size, Audit Committee Independence, audit committee meeting were found to be insignificantly related to firm performance. (Hu, Tam, and Tan 2010) employ structural equation modeling to 304 publicly listed firms for the financial period 2003-2005. Findings suggest ownership concentration have significant governance effect and have impacted negatively on firm performance. (Khan, Nemati, and Iftikhar 2011) examine 42 firms during the financial period 2007-2011. The empirical results indicate that ROA and ROE are significantly related to corporate governance. However, Earnings Per Share (EPS) did not show any significant change as an outcome of corporate governance. in general, this paper found a positive influence of corporate governance on firm performance. (Najjar 2012) uses the Pooled Data method for five listed insurance companies during the financial period of 2005-2010. Results show that there is no important effect of corporate governance represented by industry performance, ownership concentration, CEO status, the number of employees, and some shares traded on firm performance represented by ROE. On the other hand board, size and firm size have a significant impact on firm performance represented by ROE. (Nuryanah and Islam 2011) use panel data analysis during the financial period 2002-2004. Findings show that all internal mechanisms except the size of both board and audit committee, and management ownership are significant in explaining firm performance. (Shan and McIver 2011) use panel data analysis during the financial period 2001 to 2005. Findings reveal that ownership concentration is an important variable in specifying firm performance. The degree of board independence is significant, but it only appears to have a positive impact on performance in larger firms. The expertise of the supervisory board is an insignificant determinant of financial performance. (Yasser, Entebang and Abu Mansor 2011) examine a sample of 30 listed firms between 2008 and 2009. The outcome of the study provides proof of a significant positive relationship between ROE, profit margin, board size, board composition, and audit committee. However, the study could not provide a significant relationship between $\mathrm{ROE}$ and profit margin that represent firm performance measures and $\mathrm{CEO} /$ Chairman duality.

According to our readings, no study has yet examined the impact of audit quality (measured by auditor experience and rotation) on firm performance (measured by ROA and ROE) in the Egyptian business environment. 


\subsection{Theoretical Framework}

Audits serve a fundamental purpose in promoting confidence and reinforcing trust in financial information. This motive is the catalyst for our work. There are numerous theories developed trying to explain why firms exist and the reason for the differences in their organization and performance. This part encompassed a review of firm Agency Theory, auditors' Theory of Inspired Confidence, and firm Economies of Scale.

\subsubsection{Economies of Scale}

Economies of scale describe a competitive advantage that large firms have over smaller ones. It argues that firm size is related to profitability as large firms have greater strategic diversification, a greater possibility of renegotiating with clients and suppliers, greater ability to face competition, and keeping prices above the competitive level. In line with this idea, a positive association between firm size and profitability is anticipated (Serrasqueiro and Nunes 2008).

\subsubsection{Agency Theory}

Demand for audit arises from information asymmetry and agency conflicts between corporate managers, outside investors, and intermediaries. From an Agency Theory perception, (Dang 2004) clarifies that auditing financial statements are an effective monitoring mechanism that assures stakeholders that financial statements are free of material misstatements. Agency Theory has been extensively exercised in literature to study the information asymmetry between principals (shareholders) and agent (management). The principal-agent association as illustrated in the agency theory is essential to understanding how the role of an auditor has developed. The essential premise of Agency Theory is that conflicts of interest arise in corporate relationships due to the divergence of the benefits of managers and shareholders. The Agency Theory presumes that the role of the auditor is to manage the association between the manager and the owners. It is essential that the manager and the owners have a clear understanding that the auditor does not have the responsibility for the accounting. However, the auditor is responsible for making sure that the audit is adequate (Andersson and Emander, 2005). Agency theory, therefore, is a handy economic theory of accountability, which assists in clarifying the improvement of audit quality.

\subsubsection{Theory of Inspired Confidence}

Limperg observed that when a society loses confidence in the effectiveness of the audit, this, in turn, destroys the usefulness of the auditing process. Limperg's Theory of Inspired Confidence addresses both the demand for and the supply of audit services. According to Limperg, the need for audit services is the direct consequence of the participation of outside stakeholders in the firm. These stakeholders demand accountability from the management, in return for their contribution to the firm. Thus, the Theory of Inspired Confidence connects the community's needs for the reliability of financial information to the ability of audit techniques to meet these needs, and it stresses the development of the needs of the community and the methods of auditing in the course of time. Accordingly, changes in the needs of the society and changes in the auditing techniques result in changes in the auditor's function. 


\section{MlMacrothink}

International Journal of Accounting and Financial Reporting

ISSN 2162-3082

2019, Vol. 9, No. 1

There is lots of previous literature on the relationship between ownership structure, corporate governance and firm performance from developed capital markets. However, few pieces of research exist on the relationship between audit quality and the financial performance of firms from less developed capital markets. Accordingly, there is a necessity for more research on audit quality and its impact on the financial performance of firms operating in the Egyptian business environment. This work aims to fill in this existing gap. Results of related prior research efforts on the topic are mixed. Never the less, we predict our outcomes to be in line with the current Agency Theory, Economies of Scale Theory and Theory of Inspired Confidence.

Consequently, the critical objective of the study is to examine the impact of audit quality on the financial performance of non-financial institutions listed in the Egyptian Stock Exchange. This fundamental objective is broken down further to:

Determine the effect of auditor independence and auditor experience on ROA and ROE.

Thus, the formulations of the hypotheses are as follows:

H1: there is a significant effect of auditor experience and auditor independence on ROA.

$\mathrm{H} 2$ : there is a significant effect of auditor experience and auditor independence on ROE.

The auditor experience and the auditor independence measure auditing quality. The financial ratios ROA and ROE measure the firm performance. The population considered for this study is characterized as firms listed on the EGX 100, non-financial institutions, cover a five year period 2010-2014, data has not been discontinued throughout the period studied, the financial period starts $1 / 1$ ends $31 / 12$.

\section{Data and Methodology}

Here the authors take on the empirical investigation and present the results. The authors collect their data from secondary sources. The data gathered were coded and shown in tables. After that, conclusion and recommendations from the findings of the study are made. Finally, the paper provides propositions of future studies.

\subsection{Data}

The source of data collected is Mubasher Misr. The dataset contains a total of 150 firm observations, with $n=30$ from Egypt. Firms were selected by their audit reports which state their compliance with International Financial Reporting Standards (IFRS) during the period from 2010-2014 and their fiscal year end at $31^{\text {st }}$ of December.

The objective of this study is to investigate the relationship between auditor quality and firm performance. The auditor experience and auditor independence represent auditor quality. BIG 4 measures Auditor experience (this implies if the external auditor is a BIG 4 audit firm or not). ROT measures Auditor independence (this implies if the external audit firm rotates after the $10^{\text {th }}$ year maximum or not). The ROA and ROE represent firm performance.

As a result, this study includes four variables, BIG 4, ROT, ROA and ROE. 


\section{Ml Macrothink}

International Journal of Accounting and Financial Reporting

ISSN 2162-3082 2019, Vol. 9, No. 1

The variables used in this study and their measurements are as follows:

1. Profit (ROA) (net profit before taxes / total assets)

2. Profit (ROE) (net profit before taxes / total equity)

3. Auditor experience (big four will take the value of 1 , otherwise 0 )

4. Auditor independence (rotation after 10th year at most will take the value 1, otherwise 0)

From Table 1 below, it could be concluded that in both the Fixed-Effects and the Random-Effects models, the coefficient of the independent variable "BIG 4" has a positive sign, indicating that the two variables, BIG 4 and ROA, are positively related. However, the results of the T-Test showed that this relationship is statistically insignificant.

As for the independent variable "ROTATION," the coefficient - in both models - has a negative sign, indicating that the two variables, ROTATION, and ROA, are negatively related. However, this relationship is statistically insignificant.

Hausman test is used to compare the Fixed-Effects model and the Random-Effects model. Since the result is not significant $(\mathrm{P}$-value $=0.1527)$, the null hypothesis of this test is not rejected. Accordingly, the Random-Effects model is the appropriate model to be used for analyzing the data.

Table 1. Results of estimating Model 1 (ROA)

\begin{tabular}{|c|c|c|c|c|c|}
\hline \multirow{2}{*}{ Variable } & & \multicolumn{2}{|c|}{ Fixed-Effects Model } & \multicolumn{2}{|c|}{ Random-Effects Model } \\
\hline & & Coefficient & P-value & Coefficient & P-value \\
\hline $\mathrm{C}$ & & 0.084982 & 0.7744 & 0.060185 & 0.5190 \\
\hline BIG4 & & 0.038681 & 0.9323 & 0.053280 & 0.6380 \\
\hline ROT & & -0.244108 & 0.3237 & -0.012297 & 0.9545 \\
\hline \multicolumn{6}{|l|}{ Hausman test: } \\
\hline Chi-Sq. Statistic & 3.759 & & & & \\
\hline d.f. & 2 & & & & \\
\hline P-value & 0.1527 & & & & \\
\hline
\end{tabular}

Table 2 below concludes in both the Fixed-Effects and the Random-Effects models, the coefficient of the independent variable "BIG 4" has a positive sign, indicating that the two 


\section{Mll Macrothink}

International Journal of Accounting and Financial Reporting

ISSN 2162-3082

2019, Vol. 9, No. 1

variables, BIG 4 and ROE, are positively related. However, the results of the T-Test showed that this relationship is statistically insignificant.

As for the independent variable "ROTATION," the coefficient - in both models - has a negative sign, indicating that the two variables, ROTATION, and ROE, are negatively related. However, this relationship is statistically insignificant.

The Hausman test is used to compare the Fixed-Effects model and the Random-Effects model. Since the result is not significant (P-value $=0.1706)$, the null hypothesis of this test is not rejected. Accordingly, the Random-Effects model is the appropriate model to be used for analyzing the data.

Table 2. Results of estimating Model 2 (ROE)

\begin{tabular}{lllll}
\hline \multirow{2}{*}{ Variable } & \multicolumn{2}{l}{ Fixed-Effects Model } & \multicolumn{2}{c}{ Random-Effects Model } \\
\cline { 2 - 5 } & Coefficient & P-value & Coefficient & P-value \\
\hline C & 0.147220 & 0.8440 & 0.094244 & 0.6850 \\
\hline BIG4 & 0.147906 & 0.8975 & 0.170850 & 0.5446 \\
\hline ROT & -0.608206 & 0.3299 & -0.033829 & 0.9502 \\
\hline
\end{tabular}

Hausman test:

\begin{tabular}{ll} 
Chi-Sq. Statistic & 3.5366 \\
d.f. & 2 \\
\cline { 1 - 2 } P-value & 0.1706
\end{tabular}

Findings show that BIG 4 and ROT have an insignificant impact on the ROA and ROE of the firm, thus, implying that the auditor experience and auditor independence have a negligible effect on the firm profitability.

\subsection{Methodology}

This study uses the statistical package e-views. This work relies on panel data analysis to allow for differences in the form of substantial unobserved effects. Panel data combines both time series and cross-sectional techniques. It has many advantages over both methods. These include its ability to provide results that could not be estimated by the individual study of either cross-section or time-series data thus improving the effectiveness and efficiency of econometric estimations (Artikis, Asimakopoulos, et al. 2009). Furthermore, its ability to control for individual heterogeneity as well as state and time-invariant variables which are not possible with either time series or cross-sectional techniques (Baltagi 2008). 
This study applies panel random-effects regression model.

PRM

$$
\mathrm{Y}_{i t}=\mathrm{a} 0+\beta 1 \mathrm{X} 1_{i t}+\beta 2 \mathrm{X} 2_{i t}+\beta 3 \mathrm{X} 3_{i t}+\beta 4 \mathrm{X} 4_{i t}+\epsilon_{i t}
$$

Where

$\mathrm{Y}_{i t}=\mathrm{ROA}, \mathrm{X} 1=\mathrm{BIG} 4, \mathrm{X} 2=\mathrm{ROT}, \mathrm{a} 0=$ Constant; $\beta=$ The Coefficient of the variable; $\mathrm{i}=$ firm; $\mathrm{t}=$ time period and $\epsilon=$ error term.

FEM

$$
\mathrm{Y}_{i t}=\mathrm{a} 0+\beta 1 \mathrm{X} 1_{i t}+\beta 2 \mathrm{X} 2_{i t}+\beta 3 \mathrm{X} 3_{i t}+\beta 4 \mathrm{X} 4_{i t}+\epsilon_{i t}
$$

Where

$\mathrm{Y}_{i t}=\mathrm{ROE}, \mathrm{X} 1=\mathrm{BIG} 4, \mathrm{X} 2=\mathrm{ROT}, \mathrm{a} 0=$ Constant; $\beta=$ The Coefficient of the variable; $\mathrm{i}=$ firm; $\mathrm{t}=$ time period and $\epsilon=$ error term.

Hausman's test is conducted to determine whether to use fixed-effects or random-effects regression model. Since the result of the Hausman's analysis indicates that the difference in the coefficients between fixed effects and random effects is non-systematic, the study applies the random effects panel regression.

\section{Discussion of Empirical Results}

The main objective of this study is to evaluate the influence of audit quality on the firm financial performance of non-financial firms listed in the Egyptian stock exchange. As a result of the evaluation of the data content of the financial statements of nonfinancial firms operating in the Egyptian business environment and characterized as EGX 100, we notice that the majority of the firms evaluated are audited by Big 4 audit firm Hazem Hassan KPMG certified for ten years before rotation or cooling off. This is contrary to those firms that are audited by Deloitt, Ernest and Young or Price Waterhouse Cooper as these external audit firms rotate or cool off after three or five years maximum. This phenomenon is investigated, results are obtained and an explanation is given.

We apply the following five steps:

1. The use of Pooled Model on the data.

2. The use of the Fixed Effect Model on the data.

3. The comparison of the results of the Pooled Model and the Fixed Effect Model using the F-Test.

4. The use of Random Effect Model on the data.

5. The comparison of the results of the Random Effects Model and the Fixed Effect Model using the Hausman's Test to verify the appropriate model for use.

These five steps are applied when ROA represents the dependent variable and the BIG4 and 
ROT represent the independent variables and when ROE represents the dependent variable, and the BIG 4 and ROT represent the independent variables.

The Hausman test is used to compare the Fixed-Effects model and the Random-Effects model. Since the result is not significant $(\mathrm{P}$-value $=0.1527)$ and $(\mathrm{P}$-value $=0.1706)$ respectivly, the null hypothesis of this test is not rejected. Accordingly, the Random-Effects model is the appropriate model to be used for analyzing the data.

The final results imply that the independent variables (BIG4 \& ROT) have an insignificant impact on the dependent variables (ROA \& ROE), thus, suggesting that the auditor experience and auditor independence have a negligible effect on the firm profitability.

Findings of (Matoke \& Omwenga 2016) indicate that the impact of audit quality on financial performance is positive and significant and the higher the degree of an auditors independence, the higher the propensity of a firm making considerable net profit margins. The impact of auditor size was also positive and significant, although, its impact was less than that of auditor independence. The finding of (Farouk \& Hassan 2014) show that auditor size and auditor independence have significant effects on the financial performance of listed cement firms in Nigeria. However, auditor independence has a more significant effect than auditor size on business performance. The study by (Hussainey 2008) finds that investors can anticipate future earnings better when the Big4 accounting firms audit financial statements. However, the findings are not applicable to unprofitable firms.

On the contrary the statistical results of this study reveal insignificance of the audit quality (independent variable) on firm performance (dependent variable) represented by auditor experience and auditor independence (independent variables) on firm profitability (dependent variable) further broken down and described by BIG 4 and ROT (independent variables) on ROA and ROE (dependent variables) respectively. This study is more online with (Singer \& Zhang 2018) that finds that longer audit firm tenure leads to less timely discovery and correction of misstatements. In addition, it discovers that longer auditor tenure also leads to mistakes of greater magnitudes and that the Sarbanes-Oxley Act has mitigated, but not eliminated, the adverse effect of long auditor tenure. Finally, the study proves that the negative association between auditor tenure and timely discovery of misstatements is mainly present in the first two years of an audit engagement. The calls for "mandatory auditor rotation," based on concerns that longer auditor tenure reduces earnings quality motivates (Myers, Myers, \& Omer 2003).

\section{Conclusions}

At this stage of the study we come up with the conclusion from the findings that we obtain, and we propose future studies. The study examined the relationship between audit quality and firm financial performance through the proxies of (BIG4 \& ROT) on (ROA \& ROE) respectively of listed non financial firms in Egypt. Some concepts, principles and contrasting views of scholars were presented. A wide-ranging review of literature was made. Data content in financial statements during (2007-2017) has been evaluated. These firms are categorized as EGX100 (top 100 active non financial institutions listed in the Egyptian stock 
exchange). After the audit quality and data content of the firm financial statements have been evaluated, final results imply that the independent variables (BIG4 \& ROT) have an insignificant impact on the dependent variables (ROA \& ROE) respectively, thus, suggesting that the auditor experience and auditor independence have a negligible effect on the firm profitability. This study is closely related to (Singer \& Zhang 2018) that finds that longer audit firm tenure leads to less timely discovery and correction of misstatements. Also, it discovers that longer auditor tenure also leads to misstatements of higher magnitudes. Finally, the study proves that the negative association between auditor tenure and timely discovery of misstatements is mainly present in the first two years of an audit engagement. During the process undertaken to complete this study, we observed the frequency of rotation of the auditing firm off the client. We noticed that only three out of the thirty firms considered rotate audit firms every three years or five years maximum while the rest of the firms in the population changed audit firms after the $10^{\text {th }}$ year. When further investigating this phenomenon we found that there is no distinct set of standards, rules, guidelines or regulation that are imposed on the firms listed on the Egyptian stock exchange concerning the frequency of auditor rotation and that it all depends on custom and related interests. We also detected that the impact of auditor rotation on firm performance was significant during the current two years only. The period observed was 2007-2017. Evidence proves that financial statements reveal value relevant information to investors for predicting profitability. This is increased when firm financial statements are audited by one of the big four accounting firms. However, these findings are not applicable for unprofitable firms. The research findings may have important implications for audit quality literature. The findings indicate that auditor experience and auditor independence may not be the best proxy for the actual and perceived audit quality. Therefore, other variables may be considered because this type of information is important to key stakeholders in making their investment decisions. Similar to (Singer \& Zhang 2018) our study tries to answer the following research question "have the big four accounting firms lost their audit quality advantage?" The overall findings indicate that the effect of audit quality on financial performance is insignificant. Thus, we recommend that mandatory rules, regulations, and guidelines to be set and applied to control the auditor rotation frequency and transition period to ensure auditor independence. Also, we suggest that the management of listed firms employ the services of audit firms whose character and integrity is beyond question and have solid reputation.

\section{Future Research}

Due to the importance of having a high-quality audit, further studies should explore the areas that relate to audit quality such as customer service satisfaction and customer loyalty. Also, further studies may be conducted to examine the potential value of audit quality to other stakeholders. Finally, we propose future studies to be undertaken to find out if audit quality has an impact on the audit of unstructured data of a firm.

\section{Acknowledgements}

The authors gratefully acknowledge the helpful comments of Mrs. Rachael Marie Keller Bouhan, who substantially improved the article. The authors also gratefully acknowledge Dr. 


\section{MlMacrothink}

International Journal of Accounting and Financial Reporting

ISSN 2162-3082

2019, Vol. 9, No. 1

Sayed Mohamed for carrying out the statistical work presented in this study. All errors are our own. Both the authors worked equally throughout the manuscript in terms of the introduction, literature review, methodology, results, conclusion, and future studies.

\section{References}

Al-Matari, E. M., Al-Swidi, A. K., Fadzil, F. H., \& Al-Matari, Y. A. (2012). The impact of board characteristics on firm performance: Evidence from nonfinancial listed companies in Kuwaiti Stock Exchange. International Journal of Accounting and Financial Reporting, 2(2),310.

Al-Matari, E. M., Al-Swidi, A., \& Fadzil, F. H. B. (2013). The effect of the internal audit and firm performance: A proposed research framework. International Review of Management and Marketing, 4(1), 34-41.

Asimakopoulos, I., Samitas, A., \& Papadogonas, T. (2009). Firm-specific and economy wide determinants of firm profitability: Greek evidence using panel data. Managerial Finance, 35(11), 930-939.

Baltagi, B. (2008). Econometric analysis of panel data. John Wiley \& Sons.

Bouaziz, Z. (2012). The impact of auditor size on financial performance of Tunisian companies. Paper presented at the Faculty of Economics and Management. Sfax University, Tunisia.

Chiung, J. L., Tzu, T. H., \& W, C. L. (2011). Does ownership structure affect firm value? Intellectual capital across industries perspective. Journal of Intellectual Capital, 12(4), 552-570.

Dang, L. (2004). Assessing actual audit quality.

DeAngelo, L. E. (1981). Auditor size and audit quality. Journal of Accounting and Economics, 3(3), 183-199.

Emander, C., \& Andersson, C. (2005). The New Auditing Standard in Sweden-What are the effects of a more detailed auditing standard?. Rapport Nr.: Externredovisning Och Företagsanalys.

Farouk, M. A., \& Hassan, S. U. (2014). Impact of audit quality and financial performance of quoted cement firms in Nigeria. International Journal of Accounting and Taxation, 2(2), 1-22.

Fazlzadeh, A., Hendi, A. T., \& Mahboubi, K. (2011, February). The examination of the effect of ownership structure on firm performance in listed firms of Tehran stock exchange based on the type of the industry. International Journal of Business and Management, 6(3), 249.

Hu, H. W., Tam, O. K., \& Tan, M. G. S. (2010). Internal governance mechanisms and firm performance in China. Asia Pacific Journal of Management, 27(4), 727-749.

Hussainey, K. (2009). The impact of audit quality on earnings predictability. Managerial Auditing Journal, 24(4), 340-351. 


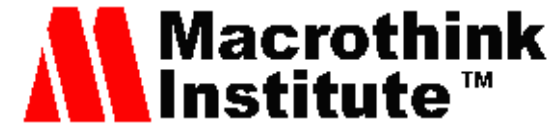

International Journal of Accounting and Financial Reporting

ISSN 2162-3082 2019, Vol. 9, No. 1

Jackson, A. B., Moldrich, M., \& Roebuck, P. (2008). Mandatory audit firm rotation and audit quality. Managerial Auditing Journal, 23(5), 420-437.

Khan, K., Nemati, A. R., \& Iftikhar, M. (2011). Impact of corporate governance on firm performance evidence from the Tobacco industry of Pakistan. International Research Journal of Finance and Economics, 61, 7-14.

Mandac1, P., \& Gumus, G. (2010). Ownership Concentration, Managerial Ownership and Firm Performance: Evidence from Turkey. South East European Journal of Economics and Business, 5(1), 57-66.

Matoke and Omwenga. (2016). Audit Quality and Financial Performance of Companies Listed in Nairobi Securities Exchange. International Journal of Scientific and Research Publications, 6(11).

Miettinen, J. (2011). The role of audit quality on the relationship between auditee's agency problems and financial information quality. Paper presented at the Department of Accounting and Finance, University of Vaasa, Finland.

Myers, J., Myers, L., \& Omer, T. (2003). Exploring the Term of the Auditor-Client Relationship and the Quality of Earnings: A Case for Mandatory Auditor Rotation?. The Accounting Review, 78(3), 779-799.

Najjar, N. J. (2012). The impact of corporate governance on the insurance firm's performance in Bahrain. International Journal of Learning and Development, 2(2), 1-17.

Nuryanah, S., \& Islam, S. (2011). Corporate Governance and Performance: Evidence From an Emerging Market. Malaysian Accounting Review, 10(1).

Obiyo, O. C., \& Lenee, L. T. (2011). Corporate governance and firm performance in Nigeria. IJEMR, 1(4), 1-12.

Oluwagbemiga, A. (2010). The Role of Auditors in Fraud Detection, Prevention and Reporting in Nigeria.

Ongore, V. O. (2011). The relationship between ownership structure and firm performance: An empirical analysis of listed companies in Kenya. African Journal of Business Management, 5(6), 2120.

Serrasqueiro, Z. S., \& Nunes, P. M. (2008). Performance and size: empirical evidence from Portuguese SMEs. Small Business Economics, 31(2), 195-217.

Shah, S. Z. A., \& Hussain, Z. (2012). Impact of ownership structure on firm performance evidence from non-financial listed companies at Karachi Stock Exchange. International Research Journal of Finance and Economics, 84, 6-13.

Shan, Y. G., \& McIver, R. P. (2011). Corporate governance mechanisms and financial performance in China: Panel data evidence on listed non-financial companies. Asia Pacific Business Review, 17(3), 301-324. 


\section{Macrothink}

International Journal of Accounting and Financial Reporting

ISSN 2162-3082 2019, Vol. 9, No. 1

Singer, Z., \& Zhang, J. (2018), Auditor Tenure and the Timeliness of Misstatement Discovery. The Accounting Review, 93(2), 315-338

Tobi, B. A., Osasrere, A. O., \& Emmanuel, U. (2016). Auditor's Independence and Audit Quality: A Study of Selected Deposit Money Banks in Nigeria. International Journal of Finance and Accounting, 5(1), 13-21.

Tsegba, I. N., \& Ezi-Herbert, W. (2011). The Relationship Between Ownership Structure and Firm Performance: Evidence from Nigerian Listed Companies. African Journal of Accounting, Economics, Finance and Banking Research, 7(7), 51.

Uwuigbe, U., \& Olusanmi, O. (2012). An empirical examination of the relationship between ownership structure and the performance of firms in Nigeria. International Business Research, 5(1), 208.

Woodland, A. M., \& Kenneth Reynolds, J. (2003). Restatements and audit quality. Working paper, Louisiana State University.

Yasser, Q., Entebang, H., \& Mansor, S. (2015). Corporate governance and firm performance in Pakistan: The case of Karachi Stock Exchange (KSE)-30.

\section{Copyright Disclaimer}

Copyright for this article is retained by the author(s), with first publication rights granted to the journal.

This is an open-access article distributed under the terms and conditions of the Creative Commons Attribution license (http://creativecommons.org/licenses/by/4.0/) 